\title{
Identificação de sentenças sintéticas (SSI) e reflexo acústico contralateral ${ }^{* * *}$
}

\author{
Synthetic sentence identification (SSI) and contralateral acoustic \\ stapedius reflex
}

\begin{abstract}
Adriana Ribeiro Tavares Anastasio* (anastasi@fmrp.usp.br)
Teresa Maria Momensohn-Santos**
\end{abstract}

\begin{abstract}
*Fonoaudióloga. Mestre em Distúrbios da Comunicação pela Pontifícia Universidade Católica de São Paulo (PUC-SP). Professora Assistente do Departamento de Oftalmologia, Otorrinolaringologia e Cirurgia de Cabeça e Pescoço da Faculdade de Medicina de Ribeirão Preto da Universidade de São Paulo.

**Fonoaudióloga. Doutora em Distúrbios da Comunicação Humana pela Universidade Federal de São Paulo. Professora Titular do Departamento de Clínica Fonoaudiológica da PUC-SP.

***Trabalho Realizado no Centro de Pesquisas Audiológicas do Hospital de Reabilitação de Anomalias Craniofaciais da Universidade de São Paulo-Bauru.
\end{abstract}

Artigo de Pesquisa

Artigo Submetido a Avaliação por Pares

Conflito de Interesse: não

Recebido em 2.03.2004

Revisado em 22.07.2004; 15.03 .2005 9.06.2005; 26.07.2005; 1.11.2005. Aceito para Publicação em 1.11.2005.

\section{Abstract}

Background: the study of the relationship of the contralateral acoustic reflex with the auditory skill of closure. Aim: to analyze the identification of a speech signal in the presence of competitive sounds in subjects with absence of contralateral acoustic reflex. Method: application of the synthetic sentence identification (SSI) test under the conditions of competitive contralateral message (SSI-CCM), with the signal-to-noise ratio of 0 and $-40 \mathrm{~dB}$, and ipsilateral competitive message (SSI-ICM), with the signalto-noise ratio of $0,-10,-15$ and $-20 \mathrm{~dB}$, in 43 young adults (group $\mathrm{A}=21$ subjects with contralateral acoustic reflex present in all of the investigated frequencies, and group $\mathrm{B}=22$ subjects with contralateral reflex absent at the frequency of $500 \mathrm{~Hz}$, or in all of the investigated frequencies, or still in some of the investigated frequencies necessarily including $500 \mathrm{~Hz}$ ), of both gender, with no hearing, otologic or learning disabilities. Results: the acoustic reflex threshold was above 100dB NA in 59\% of the individuals in group B and in $14 \%$ of the individuals in group A. All subjects performed according to the normal pattern suggested in the specialized literature for the SSI test. The performance of group B in the SSI-ICM test was inferior to that of group A for all the signal-to-noise ratios used, although the difference was not statistically significant. Group B, which presented an acoustic reflex threshold higher than 100dB NA or the absence of the acoustic reflex, was also the group that presented the worse performance in the SSI test. Conclusion: the absence of the contralateral acoustic reflex seems to interfere in the identification of the speech signal in the presence of competitive noises.

Key Words: Auditory Perception; Reflex; Acoustic; Speech Intelligibility.

\section{Resumo}

Tema: estudo da relação do reflexo acústico contralateral na habilidade auditiva de fechamento auditivo. Objetivo: analisar a identificação do sinal de fala em presença de sons competitivos em sujeitos com ausência do reflexo acústico contralateral. Método: aplicação do teste de identificação de sentenças sintéticas (SSI) nas condições mensagem competitiva contralateral (SSI-MCC), na relação sinal-ruído de 0 e -40dB e mensagem competitiva ipsilateral (SSI-ICM), na relação sinal-ruído de 0, -10, -15 e -20dB, em 43 adultos-jovens (grupo $\mathrm{A}=21$ sujeitos com presença do reflexo acústico contralateral em todas as frequiências pesquisadas e grupo $B=22$ sujeitos com ausência do reflexo na frequiência de $500 \mathrm{~Hz}$, em todas as freqüências pesquisadas ou ainda em algumas das freqüências pesquisadas, mas que incluísse $500 \mathrm{~Hz}$ ), de ambos os sexos sem queixas auditivas, otológicas ou de aprendizagem. Resultados: o limiar do reflexo acústico esteve acima de 100dB NA em 59\% dos indivíduos do grupo B e em 14\% dos indivíduos do grupo A, todos os indivíduos apresentaram desempenho de acordo com o padrão de normalidade sugerido pela literatura especializada para o teste SSI, o desempenho do grupo B no teste SSI-ICM foi inferior ao grupo A em todas as relações sinal-ruído utilizadas, embora a diferença não tenha sido estatisticamente significante, o grupo B que apresentou limiar do reflexo acústico superior a 100dB NA ou ausência do reflexo acústico também foi o que apresentou pior desempenho no teste SSI. Conclusão: a ausência do reflexo acústico contralateral parece interferir na identificação do sinal de fala na presença de ruídos competitivos.

Palavras-Chave: Percepção Auditiva; Reflexo Acústico; Inteligibilidade da Fala. 


\section{Introduction}

The auditory information is mapped and processed by the Central Auditory Nervous System and the brainstem is related to several functions, including the localization of sound, memory, acoustic reflex, and background noise attenuation (Simmons, 1964; Borg, 1973; Northern and Gabbard, 1994; Carvallo, 1996).

Several theories searched to explain the middle ear muscles' functions; the four major ones are: the intensity's protection-control theory, the ossicular chain fixation theory, the accommodation and frequency selection theory, and the labyrinth pressure regulation theory (Borg et al., 1984).

Although there is a tendency to attribute to the acoustic stapedius reflex the role of "inner ear protector", the high neural complexity of this mechanism allied with new approaches from theoretical and experimental researches (with humans and guinea pigs) have attributed other functions to the acoustic reflex of the stapedius muscle, besides the protector one.

Briefly, the acoustic reflex is important in the separation of the auditory signal from other internal noise (of the body) or environmental noise, in the speech low frequencies attenuation control favoring the perception of the high frequencies (anti-masking effect), in the attenuation of vocalized sounds, and in the speech recognition for loud intensities (Simmons, 1964; Wormald et al., 1995; Kawase et al., 1997).

In the clinical practice it is possible to find a considerable number of individuals without evident signs of middle ear and stapedius-cochlear reflexarch affection and that, even though, do not present the acoustic reflex of the stapedius muscle registration. The same way, it's possible the existence of people with normal hearing acuity and who present complaints of poor speech intelligibility when simultaneously exposed to competitive noise.

In 1965, Speaks and Jerger developed a test of Synthetic Sentences Identification (SSI) in an attempt to solve the problem of measuring the speech comprehension. The SSI contrasted with the traditional researches regarding the nature of speech material and the test procedure. In 1988, Almeida and Caetano adapted the SSI for the Portuguese language and, since then, it has been used in Brazil with different populations. The test paradigm and the sentences remained the same, but the signal-to-noise ratios were the most varied ones (Almeida and Caetano, 1988; Aquino, 1992; Aquino et al., 1993; Osterne et al., 1994; Kalil et al., 1997; Amatucci, 1998).

The SSI is a closed-message test that requests to the listener the identification of one of several alternatives of sentences associated to a competitive message which plays a role of background noise. The SSI sentences are composed by seven to nine words classified as "artificial" once the sentences are not "real", and synthetic of third order once they have specific syntax rules, where there is a dependence every three words.

The SSI test permits to analyze a set of different structures (inner ear and first neuron, brainstem intra-axial and supratentorial auditory pathway) and eliminates the pronunciation mistakes of the patient and the examiner's interpretation mistakes, besides clearly evidencing the pathological individuals from the normal ones, once it is an easy test for the normal hearing individuals and difficult for the ones with auditory pathway pathology (Almeida and Caetano, 1988).

From the assumption that the acoustic reflex of the stapedius muscle attenuates the low frequencies, and that for a better speech intelligibility it is necessary the attenuation of the background noise, the aim of this study was to study the performance of young adults with and without alteration of the contralateral registration of the acoustic stapedius reflex in the SSI test, in an attempt to verify if a hearing individual without the acoustic stapedius reflex would have difficulty in the identification of the sign in the presence of other competitive sounds.

\section{Method}

The research was approved by the Research Ethics Committee of the Rehabilitation Hospital of Craniofacial Abnormalities of the University of São Paulo, with a protocol $n^{\circ} 152 / 2003-U E P-C E P$.

This study was developed in the Audiological Research Center of the Rehabilitation Hospital of Craniofacial Abnormalities of the University of São Paulo, in Bauru -SP. The participants were graduation and pos graduation students of Speech and Hearing Sciences, soldiers from the Tiro de Guerra, and some of the researcher's colleagues. All participants volunteered and signed the Informed Consent Term in order to participate in the research. 
Subjects

Forty three young adults were selected, 20 male and 23 female, ranging in age from 18 to 25 years, without hearing, otologic or learning complaints, and with hearing thresholds (air conduction) d" 25 dBHL from 250 to $8000 \mathrm{~Hz}$ (Davis and Silverman, 1970), bilateral type A tympanometry (Jerger, 1970), speech recognition threshold compatible with the average of frequencies from 500, 1000 and $2000 \mathrm{~Hz}$, and Speech Recognition Index > than $88 \%$ with monosyllables. Of the 43 selected individuals, 21 composed group A (control), 8 men and 13 women; and 22 composed group B (experimental), 12 men and 10 women.

Group A presented, besides the inclusion criteria, the contralateral registration of the acoustic stapedius reflex in all tested frequencies.

Group B followed the same inclusion criteria as group A, except that during the acoustic reflexes testing, its subjects presented, in at least one of the tested ears, the absence of the registration in $500 \mathrm{~Hz}$, absence in all tested frequencies, or absence in some frequencies including $500 \mathrm{~Hz}$. This group was afterwards divided in B1 (10 individuals, 6 men and 4 women with the absence of registration in $500 \mathrm{~Hz}$ ), B2 (4 female individuals, with absence of the registration in all tested frequencies) and B3 ( 8 individuals, 6 men and 2 women, with absence of the registration in $500 \mathrm{~Hz}$ and in other frequencies).

The pure tone audiometry, the speech audiometry tests and the Synthetic Sentences Identification test were performed in an acoustically treated booth with a clinical two channels Madsen audiometer - Midimate 622. The acoustic and speech stimuli were provided by a TDH 39 earphone (calibration ANSI S3.6/96: ANSI S343/92; ISSO 389/ 91). The speech audiometry and the SSI were applied using a TEAC PD-P30 Portable CD player. For the speech audiometry, the trissyllable words lists proposed by Lacerda (1976) and monosyllable words lists proposed by Pen and MangabeiraAlbernaz (1973)were used; The SSI test was applied according to Pereira and Schochat (1997). The acoustic immitance measures were analyzed through a Siemens SD30 clinical Middle ear Analyzer

The acoustic reflex threshold was investigated in the frequencies from 500 to $4000 \mathrm{~Hz}$ in the contralateral condition to the tested ear. The registration was considered present when the modification in the acoustic immitance of the eardrum-ossicular system was $0,1 \mathrm{cc}$ and the threshold was considered the minimal stimulus intensity capable of triggering the system's modification.

The registration was considered absent when there was no modification in the acoustic immitance with the maximal output of the equipment, $110 \mathrm{~dB}$ for $500 \mathrm{~Hz}$ and $120 \mathrm{~dB}$ for 1000,2000 and $4000 \mathrm{~Hz}$. For statistical calculations, the fictitious value of $120 \mathrm{~dB}$ (maximum output of the equipment) was considered as a threshold in group B whenever the acoustic reflex registration was absent.

The SSI sentences were applied in both groups with an intensity of 40dBSL, based on the pure tone air conduction thresholds in the frequencies of 500,1000 and $2000 \mathrm{~Hz}$; the competitive message intensity varied according to the required in each test condition. The competitive message was presented in the conditions: contralateral (MCC) and ipsilateral (MCI) to the tested ear, always starting the test with the right ear. In the MCC condition, the sign-to-noise ratios used were 0 and $-40 \mathrm{~dB}$, and in the MCI condition they were $0,-10$, 15 and $-20 \mathrm{~dB}$. Ten sentences were presented for each sign-to-noise ratio in both ears. The correct responses were analyzed in terms of percentage, so the performance of the individuals was established by the percentage of correct responses in the different conditions of the test.

\section{Statistical method}

The Wilcoxon test was used in order to compare the right and left ears performance of groups A and $\mathrm{B}$ at different signal-to-noise ratios, in the $\mathrm{MCC}$ and MCI conditions.

In order to compare the performance in the SSI test between groups A and B in the MCC and in the MCI conditions with different signal-to-noise ratios in both ears, the Mann-Whitney test was used. For the comparison of the performance of subgroups B1, B2 and B3 in the SSI test in different test conditions, with all signal-to-noise ratios for both ears, we used the Kruskal-Wallis test. The significance level used in the tests was $\mathrm{p}<0,05$ and the significant value were shown up with a $*$

\section{Results}

Tables 1 to 3 present respectively, the descriptive analysis of the pure tone thresholds, the distribution and the average of the stapedius muscle acoustic reflex thresholds for groups $\mathrm{A}(\mathrm{n}=21)$ and for group $\mathrm{B}$ $(n=22)$.

Tables 4 and 5 present respectively the average of SSI-MCC and SSI-MCI results concerning the 
variables signal-to-noise ratio, tested group and tested ear.

The Wilcoxon test did not reveal a significant statistical difference in the performance of the right and left ears for the SSI-MCI with a signal-to-noise ratio of 0 and -40 , for groups $\mathrm{A}$ and $\mathrm{B}$.

In Table 6 , the Wilcoxon test revealed statistically significant difference for the left ear in groups $\mathrm{A}$ and $\mathrm{B}$, with a signal-to-noise ratio of 0 and -20 in group $\mathrm{A}$ and of 0 in group $\mathrm{B}$, when comparing the SSI-MCI in the signal-to-noise ratios of $0,-10,-15$ and -20 .

In Tables 7 and 8, the Mann-Whitney test did not show a statistically significant difference between groups A and B for the conditions MCC and MCI.

Graphs 1 and 2 show, respectively, the mean values of the right and left ears performance of individuals from groups $A$ and $B$ for the SSI-MCI test.
There was no significant statistical difference between the subgroups B1, B2 and B3 in the different test situations in all signal-to-noise ratios for both ears, as shows Table 9.

TABLE 1. Descriptive analysis of the pure tone thresholds of groups A $(n=21)$ and $B(n=22)$ in the right and left ears.

\begin{tabular}{ccccc} 
Grupo & Orelha & $\mathrm{X}$ & $\mathrm{M}$ & $\mathrm{dp}$ \\
\hline $\mathrm{A}$ & OD & 6,2 & 5,0 & 4,1 \\
& OE & 5,2 & 5,0 & 3,7 \\
& & & & \\
B & OD & 7,3 & 5,0 & 4,0 \\
& OE & 8,4 & 10,0 & 3,6 \\
\hline
\end{tabular}

Legenda: $\mathrm{X}=$ média; $\mathrm{M}=$ mediana; $\mathrm{dp}=$ desvio-padrão.

TABLE 2. Distribution and average of the acoustic reflex of the stapedius muscle thresholds of the individuals from group A ( $\mathrm{n}=21)$.

\begin{tabular}{|c|c|c|c|c|c|c|c|c|c|}
\hline \multirow{3}{*}{ Número } & \multicolumn{4}{|c|}{ Contralateral Direito } & \multicolumn{4}{|c|}{ Contralateral Esquerdo } & \multirow{3}{*}{$\mathrm{Hz}$} \\
\hline & 500 & 1000 & 2000 & 4000 & 500 & 1000 & 2000 & 4000 & \\
\hline & dB NA & dB NA & dB NA & dB NA & dB NA & dB NA & $\mathrm{dB} N A$ & dB NA & \\
\hline 1 & 90 & 95 & 90 & 90 & 90 & 95 & 90 & 95 & \\
\hline 2 & 100 & 95 & 90 & 85 & 95 & 100 & 90 & 90 & \\
\hline 3 & 100 & 90 & 90 & 90 & 95 & 95 & 95 & 90 & \\
\hline 4 & 90 & 85 & 85 & 85 & 90 & 85 & 90 & 95 & \\
\hline 5 & 95 & 90 & 85 & 100 & 90 & 90 & 85 & 95 & \\
\hline 6 & 100 & 95 & 95 & 100 & 95 & 90 & 90 & 90 & \\
\hline 7 & 85 & 85 & 90 & 85 & 90 & 85 & 90 & 90 & \\
\hline 8 & 95 & 90 & 95 & 90 & 95 & 90 & 90 & 85 & \\
\hline 9 & 80 & 80 & 80 & 80 & 80 & 75 & 80 & 80 & \\
\hline 10 & 100 & 100 & 90 & 95 & 100 & 90 & 90 & 90 & \\
\hline 11 & 90 & 90 & 90 & 90 & 90 & 90 & 90 & 90 & \\
\hline 12 & 95 & 95 & 100 & 105 & 110 & 90 & 90 & 85 & \\
\hline 13 & 100 & 85 & 95 & 95 & 90 & 90 & 85 & 95 & \\
\hline 14 & 90 & 90 & 90 & 110 & 100 & 90 & 100 & 115 & \\
\hline 15 & 95 & 90 & 100 & 90 & 105 & 95 & 95 & 95 & \\
\hline 16 & 90 & 80 & 85 & 80 & 85 & 70 & 75 & 70 & \\
\hline 17 & 90 & 85 & 85 & 85 & 85 & 80 & 85 & 90 & \\
\hline 18 & 95 & 85 & 90 & 80 & 85 & 90 & 90 & 85 & \\
\hline 19 & 95 & 85 & 85 & 90 & 90 & 90 & 90 & 90 & \\
\hline 20 & 95 & 90 & 90 & 90 & 95 & 90 & 90 & 95 & \\
\hline 21 & 100 & 90 & 90 & 90 & 100 & 95 & 95 & 90 & \\
\hline MÉDIA & 93,8 & 89,0 & 90,0 & 90,9 & 93,0 & 88,8 & 89,3 & 90,5 & \\
\hline
\end{tabular}


TABLE 3. Distribution and average of the acoustic reflex of the stapedius muscle thresholds of the individuals from group B ( $\mathrm{n}=22)$.

\begin{tabular}{|c|c|c|c|c|c|c|c|c|c|}
\hline \multirow{3}{*}{ Número } & \multicolumn{4}{|c|}{ Contralateral Direito } & \multicolumn{4}{|c|}{ Contralateral Esquerdo } & \multirow{3}{*}{$\mathrm{Hz}$} \\
\hline & 500 & 1000 & 2000 & 4000 & 500 & 1000 & 2000 & 4000 & \\
\hline & dB NA & $\mathrm{dB} N A$ & dB NA & $\mathrm{dB} N A$ & $\mathrm{~dB} N A$ & dB NA & dB NA & dB NA & \\
\hline 1 & A & 95 & 95 & 110 & 105 & 100 & 95 & $\mathrm{~A}$ & \\
\hline 2 & A & 110 & 100 & A & 110 & 100 & 95 & 95 & \\
\hline 3 & A & 100 & 100 & A & 100 & 105 & 100 & 120 & \\
\hline 4 & A & 105 & 110 & 120 & 110 & 105 & 105 & A & \\
\hline 5 & A & 100 & 90 & 100 & 105 & 90 & 90 & 100 & \\
\hline 6 & A & A & A & A & 95 & 95 & 100 & 90 & \\
\hline 7 & A & A & A & A & 100 & 100 & 100 & A & \\
\hline 8 & 95 & 95 & 95 & 100 & A & 100 & 100 & 100 & \\
\hline 9 & A & 100 & 95 & $\mathrm{~A}$ & 105 & 100 & 120 & A & \\
\hline 10 & A & 110 & 105 & 105 & 110 & 105 & 100 & 95 & \\
\hline 11 & 100 & 90 & 100 & 100 & A & 100 & 95 & 100 & \\
\hline 12 & 105 & 100 & 95 & 90 & A & 100 & 100 & 105 & \\
\hline 13 & 95 & 100 & 100 & 95 & A & 100 & 95 & 90 & \\
\hline 14 & A & 100 & A & A & 100 & 110 & 105 & A & \\
\hline 15 & A & 95 & 95 & 95 & 100 & 110 & 95 & A & \\
\hline 16 & A & A & A & A & 95 & 90 & 90 & 85 & \\
\hline 17 & A & 105 & 100 & 90 & A & A & A & A & \\
\hline 18 & A & 95 & 90 & 90 & 90 & 95 & 95 & 90 & \\
\hline 19 & A & 100 & 90 & 90 & 95 & 100 & 95 & 100 & \\
\hline 20 & 105 & 95 & 100 & 100 & A & 110 & 100 & 95 & \\
\hline 21 & A & 95 & 95 & 95 & 100 & 100 & 100 & 85 & \\
\hline 22 & 105 & 100 & 105 & A & A & 105 & 100 & A & \\
\hline MÉDIA & 114,7 & 102,2 & 101,8 & 106,3 & 107,2 & 101,8 & 99,7 & 105,0 & \\
\hline
\end{tabular}

Legenda: $\mathrm{A}=$ ausente.

TABLE 4. Average of the SSI-MCC results in signal-to-noise ratio of 0 and -40 regarding the variables group and tested ear. Average of the SSI-MCC results in signal-to-noise ratio of 0 and -40 regarding the variables group and tested ear.

\begin{tabular}{|c|c|c|c|}
\hline \multirow{2}{*}{ Grupo } & \multirow{2}{*}{ Orelha } & 0 & \multirow{2}{*}{$\begin{array}{c}-40 \\
\mathrm{X}\end{array}$} \\
\hline & & $\mathrm{X}$ & \\
\hline \multirow[t]{2}{*}{ A } & OD & 99,5 & 98,6 \\
\hline & $\mathrm{OE}$ & 98,1 & 100,0 \\
\hline \multirow[t]{2}{*}{ B } & OD & 98,6 & 99,5 \\
\hline & $\mathrm{OE}$ & 95,9 & 99,5 \\
\hline
\end{tabular}

Legenda: $\mathrm{OD}=$ orelha direita; $\mathrm{OE}=$ orelha esquerda. 
TABLE 5. Average of the SSI-MCI results in signal-to-noise ratio of $0,-10,-15$ and -20 regarding the variables group and tested ear.

\begin{tabular}{|c|c|c|c|}
\hline \multirow[t]{2}{*}{ Grupo } & OD & $\mathrm{OE}$ & $S / R$ \\
\hline & $X$ & $X$ & \\
\hline & 90,0 & 96,6 & 0 \\
\hline \multirow[t]{3}{*}{ A } & 88,6 & 89,9 & -10 \\
\hline & 84,8 & 84,3 & -15 \\
\hline & 64,3 & 71,9 & -20 \\
\hline \multirow[t]{4}{*}{ B } & 89,5 & 97,7 & 0 \\
\hline & 82,7 & 81,4 & -10 \\
\hline & 77,3 & 83,6 & -15 \\
\hline & 59,0 & 66,4 & -20 \\
\hline
\end{tabular}

TABLE 6. Wilcoxon test results when comparing the right and left ears, in the signal-to-noise ratios $0,-10,-15$ and -20 , in the SSI-MCI for groups $A(n=21)$ and $B(n=22)$.

\begin{tabular}{|c|c|c|c|c|c|c|c|c|}
\hline \multirow{3}{*}{ Grupo } & \multicolumn{6}{|c|}{ SSI/MCI } & \multirow[b]{3}{*}{$\mathrm{S} / \mathrm{R}$} & \multirow[b]{3}{*}{$\mathrm{p}$} \\
\hline & \multicolumn{3}{|c|}{ OD } & \multicolumn{3}{|c|}{$\mathrm{OE}$} & & \\
\hline & $\mathrm{X}$ & M & $\mathrm{dp}$ & $\mathrm{X}$ & M & $\mathrm{dp}$ & & \\
\hline & 90,0 & 90,0 & 10,5 & 96,6 & 100,0 & 6,5 & 0 & $0,026238^{*}$ \\
\hline \multirow[t]{3}{*}{ A } & 88,6 & 90,0 & 10,1 & 89,9 & 90,0 & 10,9 & -10 & 0,550928 \\
\hline & 84,8 & 80,0 & 9,8 & 84,3 & 80,0 & 8,7 & -15 & 0,294515 \\
\hline & 64,3 & 70,0 & 13,9 & 71,9 & 70,0 & 10,0 & -20 & $0,021950 *$ \\
\hline \multirow[t]{4}{*}{ B } & 89,5 & 90,0 & 7,8 & 97,7 & 100,0 & 5,3 & 0 & $0,004052 *$ \\
\hline & 82,7 & 80,0 & 14,5 & 81,4 & 85,0 & 13,5 & -10 & 0,0704910 \\
\hline & 77,3 & 80,0 & 16,3 & 93,6 & 80,0 & 9,0 & -15 & 0,111938 \\
\hline & 59,0 & 60,0 & 16,0 & 66,4 & 70,0 & 9,5 & -20 & 0,050032 \\
\hline
\end{tabular}

*diferença estatisticamente significante $(\mathrm{p}<0,05)$

Legenda: $\mathrm{X}=$ média; $\mathrm{M}=$ mediana; $\mathrm{dp}=$ desvio padrão; $\mathrm{MCI}=$ Mensagem Competitiva Ipsilateral.

TABLE 7. Mann-Whitney test results in the comparison of the SSI-MCC, in the signal-to-noise ratios of 0 and -40 , for the right and left ears, between groups A $(n=21)$ and $B(n=22)$.

\begin{tabular}{cc|ccc} 
& \multicolumn{4}{|c}{ SSI-MCC } \\
Condição & S/R & AXB & $\mathrm{p}$ \\
& & Orelha & $\mathrm{U}$ & \\
MCC & 0 & direita & 210,50 & 0,322304 \\
MCC & -40 & direita & 208,50 & 0,277350 \\
MCC & 0 & esquerda & 180,5 & 0,123076 \\
MCC & -40 & esquerda & 220,50 & 0,328572
\end{tabular}


TABLE 8. Mann-Whitney test results in the comparison of the SSI-MCI, in the signal-to-noise ratios of $0,-10,-15$ and -20 for the right and left ears, between groups $A(n=21)$ and $B(n=22)$.

\begin{tabular}{cc|ccc} 
& & \multicolumn{3}{c}{ SSI-MCI } \\
Condição & $\mathrm{S} / \mathrm{R}$ & Orelha & $\mathrm{U}$ & $\mathrm{p}$ \\
& & direita & 211,00 & 0,607438 \\
MCI & 0 & direita & 177,50 & 0,179705 \\
MCI & -10 & direita & 171,00 & 0,132519 \\
MCI & -15 & direita & 192,00 & 0,332257 \\
MCI & -20 & & & \\
& & esquerda & 216,50 & 0,619332 \\
MCI & 0 & esquerda & 155,00 & 0,055215 \\
MCI & -10 & esquerda & 222,00 & 0,816939 \\
MCI & -15 & esquerda & 170,00 & 0,114840 \\
MCI & -20 & & &
\end{tabular}

*diferença estatisticamente significante $(\mathrm{p}<0,05)$

Legenda: $\mathrm{MCI}=$ Mensagem Competitiva Ispilateral; $\mathrm{S} / \mathrm{R}$ = Relação Sinal-Ruído.

TABLE 9. Kruskal-Wallis results in the comparison of the SSI-MCC and SSI-MCI in all S/N ratios regarding the right and left ears, between the subgroups B1, B2 and B3.

\begin{tabular}{|c|c|c|c|c|}
\hline \multirow{2}{*}{ Condição } & \multirow{2}{*}{ Orelha } & \multicolumn{2}{|c|}{ SSI } & \multirow{2}{*}{$\mathrm{p}$} \\
\hline & & $\mathrm{S} / \mathrm{R}$ & $\mathrm{H}$ & \\
\hline MCC & OD & 0 & 0,94 & 0,6252 \\
\hline MCC & OD & -40 & 4,45 & 0,1054 \\
\hline MCC & $\mathrm{OE}$ & 0 & 0,17 & 0,9183 \\
\hline MCC & $\mathrm{OE}$ & -40 & 1,20 & 0,5488 \\
\hline MCI & OD & 0 & 2,05 & 0,3578 \\
\hline MCI & OD & -10 & 0,32 & 0,8532 \\
\hline MCI & OD & -15 & 0,91 & 0,6338 \\
\hline MCI & OD & -20 & 0,62 & 0,7321 \\
\hline MCI & $\mathrm{OE}$ & 0 & 5,56 & 0,0621 \\
\hline MCI & $\mathrm{OE}$ & -10 & 0,17 & 0,9125 \\
\hline MCI & $\mathrm{OE}$ & -15 & 1,43 & 0,4904 \\
\hline MCI & $\mathrm{OE}$ & -20 & 0,26 & 0,8774 \\
\hline
\end{tabular}

*diferença estatisticamente significante $(\mathrm{p}<0,05)$

Legenda: $\mathrm{MCC}=$ Mensagem Competitiva Contralateral; $\mathrm{MCI}=$ Mensagem Competitiva Ipsilateral; S/R = Relação Sinal-Ruído. 


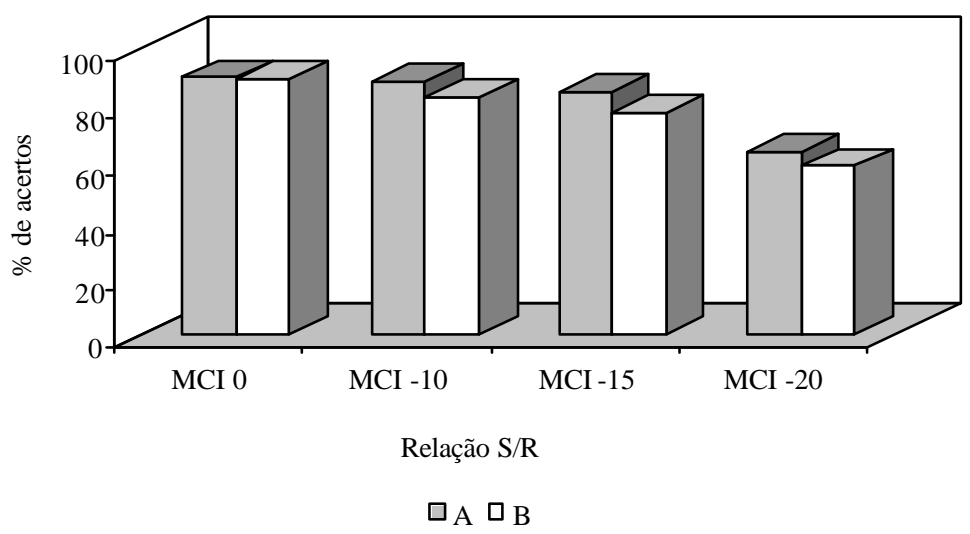

GRÁPH 2. Mean values analysis of the left ear performance of individuals from group A $(n=21)$ and group B $(n=22)$ in the SSI-MCI test.

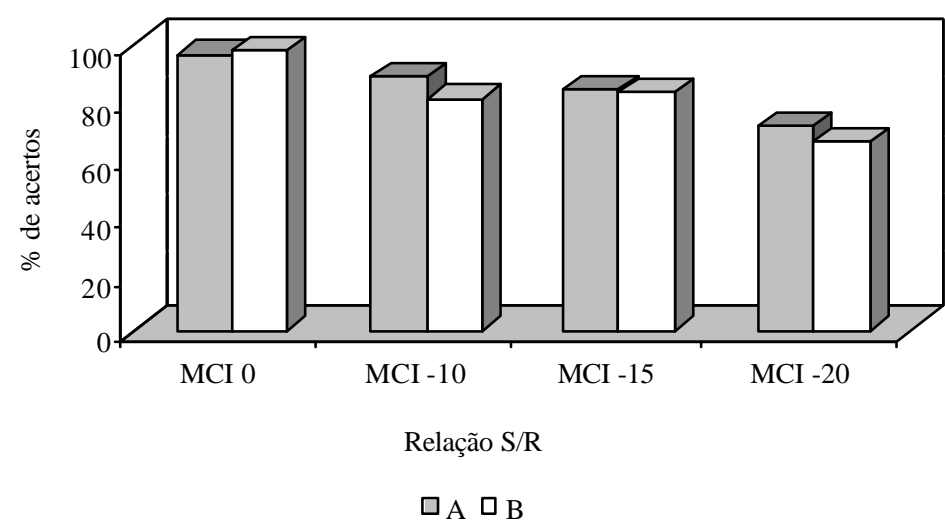

\section{Discussion}

From Borg's (1973) work, the role of the acoustic reflex in the transmission of sound information was exhaustively investigated.

Due to ethical matters, the experimental studies in human beings focused the different registration techniques of the acoustic reflex, its application at the clinic and at the topodiagnosis of hearing disorders (Borg et al., 1990; Wiley and Fowler, 1997).

The study on the relation between the acoustic reflex of the stapedius muscle and the central auditory processing had as a start point for the Brazilian scientific production, Carvallo's (1996) study. The researches that proposed to study the relation between the acoustic reflex in the speech intelligibility used as stimuli: synthesized vowels, monosyllable or dissyllable words associated or not with a masking noise, and the dichotic hearing test with words (Colletti et al., 1992; Colletti and
Fiorino, 1994; Wormald et al., 1995; Higson et al., 1996; Meneguello, et al., 2001; Marotta et al., 2002a and Marotta et al., 2002b).

Up until now, we did not find in the literature scientific work using the SSI in order to analyze the relation between the acoustic reflex and the speech intelligibility.

Buchweitz (2003) evaluated 69 elementary school's third grade students, ranging in age from 8 to 10 years old and analyzed the influence of the acoustic reflex on the responses for the speech test with competitive noise, comparing with the auditory complaint and the tested ear. Children underwent the speech test with noise in the signalto-noise ratio of -5 , absent and +5 . They were divided in two groups: A, composed by 52 ears with the acoustic reflex present at 3 to 4 tested frequencies; and B, composed by 86 ears without the acoustic reflex or with an alteration at two or 
more tested frequencies. The findings on the acoustic reflex regarding the speech test with noise showed a greater number of ears with alteration in group B, in the signal-to-noise ratio of -5 . The results showed that children presenting hearing complaint did not demonstrate significant alterations in the speech test, however they were the largest group without the acoustic reflex or with an alteration of it.

Riuto (2003) analyzed the influence of the acoustic reflex on the speech recognition responses in a monotic situation, using the Pediatric Speech Intelligibility Test (PSI), in a school children population from the $1^{\text {st }}$ and $2^{\text {nd }}$ grades of elementary school. The population was divided in two groups (A and B). In group A, children presented the acoustic reflex at all tested frequencies and in group B, they presented alteration or no acoustic reflex at one or more tested frequencies. The results revealed a higher occurrence of PSI alteration in group B, concluding that the acoustic reflex of the stapedius muscle influenced on the auditory skill of selective attention, when recognizing speech with competitive noise.

Linares and Carvallo (2004), despite having studied the latency of acoustic reflex of the stapedius muscle in children with and without auditory processing disorder, concluded that alterations on the acoustic reflex cause more harm in the auditory processing and that individuals with alteration of the acoustic reflex, even with normal audiometric evaluation should be submitted to auditory processing assessment whenever there is a complaint.

Even with different methodological approaches, there seems to be a consensus between the authors that individuals without the acoustic reflex of the stapedius muscle have worse performance in tests involving the auditory processing of information (Colletti et al., 1992; Colletti and Fiorino, 1994; Wormald et al., 1995; Carvallo 1996; Higson et al., 1996; Meneguello, et al., 2001; Marotta et al., 2002a; Marotta et al., 2002b; Buchweitz, 2003; Riuto,2003; Linares and Carvallo, 2004).

In this study, we proposed to study the speech recognition skill with competitive message, applying the SSI in adult individuals with and without the registration of the acoustic reflex of the stapedius muscle.

We chose this test in an attempt to identify subtle brainstem alterations, since the studied population did not present hearing complaints of any kind, and, therefore, we searched to verify the existence of possible relationships between the acoustic reflex of the stapedius muscle and the identification of the speech signal (sentence) in the presence of competitive sounds. Besides studying the influence of the acoustic reflex of the stapedius muscle on the speech intelligibility, we were interested in discussing which factors could justify the absence of its registration, even in individuals without hearing thresholds and middle ears alterations.

We observed that the average of the contralateral acoustic reflex thresholds from 500 to $4000 \mathrm{~Hz}$ of group A individuals were very similar for the right and left ears (Table 2). The mean values for the frequencies of 500 to $4000 \mathrm{~Hz}$ are lower than the results found by Silverman, Silman and Miller (1983) who found an average for both ears of 95,1dBHL, 93,4dBHL, 95,9dBHL and 95,7dBHL in the frequencies of 500 to $4000 \mathrm{~Hz}$. On the other hand, our results are similar to the ones obtained by Hall and Weaver (1979), where the mean values were 90dBHL, 89dBHL, 89dBHL and 90dBHL for both ears. The mean value of the acoustic reflex threshold in group B varied from $99,7 \mathrm{dBHL}$ to $114,7 \mathrm{dBHL}$ (Table 3). Several authors agree that the mean value of the pure tone hearing threshold is 85dBHL (Borg et al., 1990; Northern and Gabbard, 1994). In hearing disabled populations, Higson et al., (1996) found a mean value of the acoustic reflex threshold of $83 \mathrm{dBHL}$ against $83,4 \mathrm{dBHL}$ of the control group.

In another analysis, we verified that group A individuals number 12, 14 and 15 (Table 2) presented acoustic reflex threshold over 100dbHL in at least one of the tested ears, totalizing $14 \%$ of this group.

These results disagree with the studies of Margolis and Levine (1991) and Northern and Gabbard (1994), but they are compatible with the ones found by Carvallo (1996). Analyzing group B individually (Table 3), 13 subjects presented thresholds above 100dBHL, in the frequencies where the acoustic reflex was registered, representing $59 \%$ of the sample. We verified that even when the average of pure tone thresholds was similar between the groups, group B presented $59 \%$ of its individuals with acoustic reflex thresholds above 100dBHL.

The sample of this study was composed by individuals with normal hearing thresholds and tympanograms, and even though, presented alteration of the acoustic reflex of the stapedius muscle. In the researched literature, we found reference to the absence of acoustic reflex in 
individuals with normal hearing and normal middle ear condition in Jerger, Jerger and Mauldin (1972), Hall and Weaver (1979), Carvallo (1996), Buchweitz (2003), Riuto (2003) and Linares and Carvallo (2004).

The absence of the acoustic reflex in certain frequencies would not be expected in group $\mathrm{B}$, once it presented enough hearing thresholds for triggering the reflex. We questioned if this absence of the acoustic reflex registration, or the increasing of its threshold could be a sign of an efferent pathway disorder and, therefore, result in the damage of some functions, such as signal detection in the presence of noise.

We also questioned, with these findings, the possibility of this be a previous signal of low central auditory nervous system disease, hypothesis motivated by the specialized literature studies of the past years that related the absence of the acoustic reflex in normal hearing subjects with normal middle ear condition to auditory processing disorders in a population considered to be "audiologically" normal (Carvallo, 1996; Musiek and Oxholm, 2000; Meneguello, et al., 2001; Marotta et al., 2002a; Marotta et al., 2002b; Buchweitz, 2003; Riuto, 2003; Linares and Carvallo,2004).

Thus, the absence of the acoustic reflex registration in normal hearing individuals without hearing complaints must be further investigated.

Both groups presented an average performance compatible to the normal standards cited in the national and international literature, in the SSI-MCC and SSI-MCI tests (Jerger and Jerger, 1975; Russolo and Poli, 1983; Almeida and Caetano, 1988; Aquino, 1992; Aquino et al., 1993; Osterne et al., 1994; Amatucci, 1998). Analyzing the average of correct responses in the tests, we can say that the tested individuals did not present alteration in the auditory skill of speech recognition with competitive message.

When we compared the performance in the SSIMCI test between both ears for groups A and B (Table 6), the results obtained in the signal-to-noise ratio of -20 specifically called our attention, once group A presented significant improvement when the second ear was tested (left ear), which could not be observed in group B. We believe that this better performance may have occurred because the left ear was always the second ear to be tested and, therefore, capable of learning suggesting, then, that the ears should be alternated when applying the SSI. However, in the situation where there was a more difficult listening situation, group B didn't take advantage of that.
Our results did not present statistically significant difference between the groups concerning the performance in the SSI-MCC and SSI-MCI tests (Tables 8 and 9). The mean percentage value of correct responses in the SSIMCI for group A $(93,3 \%, 88,8 \%, 85 \%$ and $68 \%)$ and for group B $(93,6 \%, 82 \%, 80,3 \%$ and $62,7 \%)$ in the signal-to-noise ratios of $0,-10,-15$ and -20 , respectively, were in accordance with the normal standards proposed by Jerger and Jerger (1975), Jerger and Hayes (1977), Aquino (1992) and Aquino et al., (1993).

Even without a statistical difference between group A's performance in the SSI-MCI test and group B's, we stress the better performance of group $\mathrm{A}$ in relation to group $\mathrm{B}$, as seen in graphs 1 and 2 .

The subdivision of group B was critically analyzed; it aimed at determining whether there was some kind of relation between the performance in the SSI and the frequency in which the reflex was absent. Subgroups B1, B2 and B3 underwent statistical analysis for the performances comparison (Table 9). There was no significant statistical difference found, however, we stress that when we subdivided group B, we created subgroups with reduced numbers of individuals, which implies in carefulness when generalizing such information, once the absence of a statistical difference may not correspond to the findings in larger populations.

Although the SSI being broadly recommended for the topodiagnosis of brainstem cortical lesions, maybe it is not the most recommended test for subtle disorders of brainstem, such as in the case of absence of acoustic reflex of the stapedius muscle in the presence of normal hearing.

\section{Conclusion}

The main findings of this study allow us to conclude that:

- although the average pure tone thresholds of groups A and B were very similar, group B presented $59 \%$ of individuals with acoustic reflex threshold above 100dBHL;

. both groups presented performance in accordance with normal standards suggested by the national and international literature regarding SSI-MCC and SSI-MCI tests;

- although not existing a statistically significant difference between the performance of the groups, group B presented worse performance in the SSIMCI test and presented increased acoustic reflex thresholds or no registration of it; 
- there was no statistical difference between the performance of the subgroups B1, B2 and B3; - the absence of the acoustic reflex registration in individuals with normal hearing thresholds and normal tympanogram must be further investigated.

\section{References}

ALMEIDA, C. I. R.; CAETANO, M. H. U.Logoaudiometria utilizando sentenças sintéticas: synthetic sentences speech test. Rev. Bras. Otorinolaringol., São Paulo, v. 54, n. 3, p. 68-72, 1988.

AMATUCCI, M. A. F. C. Processamento auditivo central: teste SSI (Identificação de Sentenças Sintéticas) e de localização sonora em mulheres jovens, adultas e idosas. 1998. 148 f. Dissertação (Mestrado em Distúrbios da Comunicação Humana) - Universidade Federal de São Paulo, São Paulo.

AQUINO, A. M. C. M. Avaliação do sistema auditivo central pelo teste de identificação de sentenças sintéticas (SSI) com mensagem competitiva. 1992. 117 f. Dissertação (Mestrado em Otorrinolaringologia) - Faculdade de Medicina de Ribeirão Preto, Universidade de São Paulo, Ribeirão Preto.

AQUINO, A. M. C. M.; ALMEIDA, C. I. R.; OLIVEIRA, J. A. A. Teste de identificação de sentenças sintéticas (SSI) em português com mensagem competitiva: uma padronização. Rev. Bras. Otorinolaringol., São Paulo, v.59, n. 3, p. 160-163, 1993.

BORG, E. On the neuronal organization of the acoustic middle ear reflex: a physiologic and anatomical study. Brain Res., Amsterdam, v. 49, n. 1, p. 101-123, jan. 1973.

BORG, E.; COUNTER, S. A.; ENGSTROM, B.; LINDE, G.; MARKLUND, K. Stapedius reflex thresholds in relation to tails of auditory nerve fiber frequency tuning curves. Brain Res., Amsterdam, v. 506, n. 1, p. 79-84, jan. 1990.

BORG, E.; COUNTER, S. A.; RÖSLER, G. Theories of middle-ear function. In: SILMAN, S. The acoustic reflex: basic principles and clinical applications. New York: Academic Press, 1984. cap. 3, p. 63-99.

BUCHWEITZ, C. H. O papel do reflexo acústico no desempenho de crianças de $3^{a}$ série no reconhecimento de fala na presença de ruído. 2003. 83 f. Dissertação (Mestrado em Fonoaudiologia) - Pontifícia Universidade Católica de São Paulo, São Paulo.

CARVALLO, R. M. M. O efeito do reflexo estapediano no controle da passagem da informação sonora. In: SCHOCHAT, E. (Org.). Processamento auditivo. São Paulo: Lovise, 1996. cap. 3, p. 57-73. (Série Atualidades em fonoaudiologia v. 2).

COLLETTI, V.; FIORINO, F. G. Stapedotomy with stapedius tendon preservation: technique and long-term results. Otolaryngol. Head Neck Surg., Rochester, v. 111, n. 3, p. 181-188, sept. 1994.
COLLETTI, V.; FIORINO, F. G.; VERLATO, G.; CARNER, M. Acoustic reflex in frequency seletivity: brain stem auditory evoked response and speech discrimination. In: KATZ, K.; STECKER, N. A.; HENDERSON, D. Central auditory processing: a transdisciplinary view. Saint Louis: Mosby Year Book, 1992. cap 3, p. 39-46.

DAVIS, H.; SILVERMAN, R. S. Hearing and deafness. New York, Holt, Rinehart, Winston, 1970. Disponível em: <http://www.hrw.com>.

HALL, J. W.; WEAVER, T. Impedance audiometry in a young population: the effect of age, sex and tympanogram abnormalities. J. Otolaryngol., Toronto, v. 3, n. 3, p. 210-222, june 1979

HIGSON, J. M.; MORGAN, N.; STEPHENSON, H.; HAGGARD, M. P. Auditory performance and acoustic reflexes in young adults reporting listening difficulties. $\mathrm{Br}$. J. Audiol., London, v. 30, n. 6, p. 381-387, dec. 1996.

JERGER, J. Clinical experience with impedance audiometry. Arch. Otolaryngol., Chicago, v. 92, n. 4, p. 311-324, oct. 1970.

JERGER, J.; HAYES, D. Diagnostic speech audiometry.Arch. Otolaryngol., Chicago, v. 103, n. 4, p. 216-222, apr. 1977.

JERGER, J.; JERGER, S. Clinical validity of central auditory tests. Scand Audiol., Copenhagen, v. 4, n. 1, p. 147-163, 1975.

JERGER, J.; JERGER, S.; MAULDIN, L. Studies in impedance audiometry. I. Normal and sensorineural ears. Arch. Otolaryngol., Chicago, v. 96, n 6, p. 513-523, dec. 1972.

KALIL, D. M.; ZILIOTTO, K. N.; ALMEIDA, C. I. R. SSI em português. In: SCHOCHAT, E. (Org.). Processamento auditivo central: manual de avaliação. São Paulo: Lovise, 1997. Parte 2, Teste 4. p. 129-136. (Série Atualidades em fonoaudiologia v. 2).

KAWASE, T.; HIDAKA, H.; TAKASAKA, T. Frequency summation observed in the human acoustic reflex. Hear. Res., Amsterdam, v. 108, n. 1-2, p. 37-45, june 1997.

LACERDA, A. P. Audiologia clínica. Rio de Janeiro: Guanabara Koogan, 1976. 199 p.

LINARES. A. E.; CARVALLO, R. M. M. Latência do reflexo acústico em crianças com alteração do processamento auditivo. Arq. Otorrinolaringol., v. 8, n. 1, p. 11-18, 2004.

MARGOLIS, R. H.; LEVINE, S. C. Acoustic reflex measures in audiologic evaluation. Otolaryngol. Clin. North. Am., v. 24, n. 2, p. 329-347, apr. 1991. 
MAROTTA, R. M. B.; QUINTERO, S. M.; MARONE, S. Avaliação do processamento auditivo por meio do teste de reconhecimento de dissílabos em tarefa dicótica SSW em indivíduos com audição normal e ausência do reflexo acústico contralateral. Rev. Bras. Otorrinolaringol., v. 68, n. 2, p. 254-261, mar.-abr. 2002a.

MAROTTA, R. M. B.; QUINTERO, S. M.; MARONE, S. Estudo comparativo entre os achados dos testes SSW e reflexo acústico em indivíduos adultos com audição normal. Arq. Otorrinolaringol., v. 6, n. 2, p. 104-112, 2002 b.

MENEGUELLO, J.; DOMENICO, M. L. D.; COSTA, M. C. M.; LEONHARDT, F. D.; BARBOSA, L. H. F.; PEREIRA, L. D. Ocorrência de reflexo acústico alterado em desordens do processamento auditivo. Rev. Bras. Otorrinolaringol., v. 67 , n. 6, p. 830-835, nov.-dez. 2001.

MUSIEK, F.; OXHOLM, V. B. Anatomy and physiology of the central auditory nervous system: a clinical perspective. In: ROESER, R. J.; VALENTE, M.; HOSFORD-DUNN, H. Audiology: diagnosis. New York: Thieme, 2000. cap. 3, p. 45-72.

NORTHERN, J. L.; GABBARD, S. A. The acoustic reflex., In: KATZ, J. (Ed.). Handbook of clinical audiology. 4. ed. Baltimore: Williams Wilkins, 1994. cap. 21, p. 300-316.

OSTERNE, F. J.; COSTA, S. A; PEREIRA, L. D.; BORGES, A. C. L. C. Teste de identificação de frases sintéticas (SSI): aplicação em adultos com audição normal. In: ENCONTRO INTERNACIONAL DE AUDIOLOGIA, 9., 1994, Bauru. Anais... Bauru: Hospital de Pesquisa Reabilitação Lesões Lábio Palatais, Universidade de São Paulo, 1994. p. 88.

PEN, M. G.; MANGABEIRA-ALBERNAZ, P. L. Desenvolvimento de testes para logoaudiometria: discriminação vocal. In: CONGRESSO PAN-AMERICANO DE OTORRINOLARINGOLOGIA Y BRONCOESOFASOLOGIA, 1973 Lima. Anales... Lima: [s.n.], 1973. p. 223-226.
PEREIRA, L. D.; SCHOCHAT, E. Processamento auditivo central: manual de avaliação. São Paulo: Lovise, 1997. $225 \mathrm{p}$.

RIUTO, M. S. O reflexo acústico do músculo estapédio e o reconhecimento de sentenças na condição monótica em escolares. 2003. 66 f. Dissertação (Mestrado em Fonoaudiologia) - Pontifícia Universidade Católica de São Paulo, São Paulo.

RUSSOLO, M.; POLI, P. Lateralization, impedance, auditory brain stem response and synthetic sentence audiometry in brain stem disorders. Audiology, Basel, v. 22, n. 1, p. 50-62, 1983.

SILVERMAN, C. A.; SILMAN, S.; MILLER, M. H. The acoustic reflex threshold in aging ears. J. Acoust Soc. Am., New York, v. 73, n. 1, p. 248-255, jan. 1983.

SIMMONS, F. B. Perceptual theories of middle ear muscle function. Ann. Otol. Rhinol. Laryngol., Saint Louis, v. 73, n. 1, p. 724-739, 1964.

SPEAKS, C.; JERGER, J. Method for measurement of speech identification. J. Speech. Hear. Res., Washington, v. 8. n. 1, p. 185-194, 1965.

WILEY, T. L.; FOWLER, C. G. Stapedius reflex measures. In: WILEY, T. L.; FOWLER, C. G. Acoustic immitance measures in clinical audiology: a primer. London: Singular, Publishing Group, 1997. cap. 6, p. 77-114.

WORMALD, P. J.; ROGERS, C.; GATEHOUSE, S. Speech discrimination in patients with Bell's palsy and a paralysed stapedius muscle. Clin. Otolaryngol., Oxford, v. 20, n. 1, p. 59-62, feb. 1995 . 